\title{
Prospective science teachers as e-learning designers
}

\author{
Matthew Kearney \\ University of Technology, Sydney
}

\begin{abstract}
The study investigated the efficacy of prospective teachers authoring and using their own online learning designs as a means of creating links between theory classes and their teaching practicum. Trainee primary and secondary teachers adopted an exemplary, well-researched learning design to inform their own specific task designs, and used them in the context of science lessons on their practicum. This process aided teachers' development of pedagogical and science content knowledge and helped them develop ICT teacher competencies.
\end{abstract}

\section{Introduction}

This study builds on current interest in online learning designs by investigating their potential role in teacher education. It uses the context of prospective science teachers adapting and using a sample, well-researched learning design, predict-observe-explain strategy supported by multimedia (Kearney, 2002a), to facilitate a range of teacher learning outcomes. As well as developing their pedagogical knowledge, the prospective teachers revised and learned new science material and became aware of their own alternative conceptions. Furthermore, they started to appreciate children's personal science views, the value of listening to and probing these views and the challenge of confronting them. The student teachers' immersion in this e-learning design process acted as a rich context for a range of significant teacher learning experiences.

\section{Background}

\section{Theoretical perspective}

Over the past decade, the field of educational technology has endorsed constructivism as a suitable referent for the development and meaningful use of appropriate software in education (Duffy \& Cunningham, 1996). The core view of learning from a constructivist perspective suggests that 
learners actively construct (rather than acquire) their own knowledge, strongly influenced by what they already know. Learning is a social process of making sense of experience, constructing new representations of reality and further negotiating meaning through social activity, discourse and debate (Tobin \& Tippins, 1993). In this study, learning was viewed from this constructivist perspective.

\section{Learning designs}

The term 'learning designs' refers to a coordinated set of online activities designed to support conceptual change among learners (Oliver, 2001). These web based learning sequences take advantage of the online medium to make accessible effective learning strategies, supported by appropriate structures and resources (Oliver and Herrington, 2003). Researchers have recently identified and explored the underpinning support structures and learning strategies incorporated in exemplary online learning designs, particularly from tertiary education contexts (Agostinho, Oliver, Harper, Hedberg \& Wills, 2002; Laurillard \& McAndrew, 2003).

Investigating how teachers might adapt and use exemplary online learning designs is in its infancy and has so far mainly focused on tertiary teachers (eg. Bennett, Lockyer \& Agostinho, 2004). This study investigated pertinent issues involved in using these designs in pre-service teacher education and introduces prospective secondary and primary teachers as important stakeholders in the learning design research agenda.

\section{Current problems with teacher education}

A problem facing teacher education is the resilient nature of student teachers' beliefs that shape their (face to face and online) classroom practices and the need to provide them with opportunities to discuss and reflect critically on these beliefs. For example, pre-service science teachers study a variety of constructivist learning principles and strategies in theory classes at university, and are exposed to an increasing range of exemplary online learning designs in their studies. However, they often struggle to implement theory into practice (Fang, 1996) and there is good evidence that when faced with the hectic demands of everyday teaching duties, they revert to more traditional didactic teaching methods (Goodrum, Hackling \& Rennie, 2001). Furthermore, their design of online activities tends to be pedagogically shallow and content driven. This study investigates possible ways of improving this situation.

Science teacher education was chosen as the context for this study as problems in this domain are well documented (Goodrum et al., 2001) and the sample learning design chosen is grounded in the science education research literature. 


\section{Sample exemplary learning design used in this study}

The science education literature is filled with details of effective strategies to support student learning. For example, strategies informed by a constructivist perspective have been extensively reported, particularly strategies that support students' understanding of difficult concepts (eg. Treagust, Duit \& Fraser, 1996). One such strategy is the predict-observeexplain (POE) strategy. It has been used widely for over two decades as an assessment tool to probe learner's conceptual understanding and more generally as a tool to encourage quality peer learning. This strategy involves learners predicting the result of a demonstration and discussing the reasons for these predictions, observing the demonstration and finally explaining any discrepancies between their predictions and observations (White \& Gunstone, 1992). Although the strategy is well researched (eg. Champagne, Klopfer \& Anderson, 1980; Gunstone, 1995; Liew \& Treagust, 1995), few studies have investigated the use of these tasks in teacher education. An exception was Palmer's (1995) study that investigated the process of prospective primary school teachers creating their own (non computer based) POE tasks to use as teacher centred, classroom based learning activities. He reported that the prospective primary teachers found the strategy to be a potentially useful formative assessment tool for their teaching.

Multimedia supported predict-observe-explain (POE) tasks use the wellresearched POE learning strategy to effectively scaffold students' learning in a computer mediated environment, presenting digital demonstrations set in real life contexts as stimuli for their learning. The online environment gives students extra control over the pacing of their POE tasks and facilitates peer discussions; while the use of digital media to present demonstrations has significant affordances for learners' observation processes (Kearney, 2002b). This particular online learning design was chosen for use in this study because it is well researched, has been nominated as an exemplary design in a major Australian University Teaching Committee project (Agostinho et al., 2002), and was already included in the teacher education curricula at University of Technology, Sydney (UTS). Also, there were existing web based templates (Kearney \& Wright, 2002) to help participants in the study build their own online POE tasks to suit their own curriculum contexts.

\section{Study design}

Mainly qualitative data sources were used in this study, within an interpretive methodology (Erickson, 1986, Lincoln \& Guba, 1985), to provide insights into pre-service teachers as online learning designers. The study explored the following main research question using the context of 
prospective science teachers creating their own multimedia supported POE tasks (at university) before using them in a school based teaching setting: To what extent does pre-service teachers' authoring and use of an online learning design enhance their development as teachers? Subsidiary questions included: To what extent do they develop their pedagogical, technical and science content knowledge? To what extent is their understanding of the sample learning design (POE strategy supported by multimedia) enhanced?

Twenty-one prospective primary and secondary teachers from undergraduate teacher education programs at UTS chose to participate in this study. They were advised that participation in the study would not influence their grades in their course and there was no background technical skill requirement (approximately one half of the participants indicated they had limited experience with computers). At the commencement of the study, all student teachers had been exposed to the principles of the POE strategy, and used examples of POE tasks in a range of topics. The fourteen prospective primary teacher participants had completed several one-month teaching practicums in primary schools and had also completed science method subjects. The seven prospective secondary teacher participants had completed one teaching practicum and were in the process of completing their science method subjects. Pseudonyms are used in this paper to protect individuals' identities.

The student teachers were given one whole semester to design and create their own multimedia based POE tasks before using them in a primary or secondary classroom during their practicum. The design process included consultation with appropriate science education literature and also with relevant syllabus documents. For example, alternative conceptions literature (eg. Driver, Squires, Rushworth \& Wood-Robinson, 1994) was consulted to find appropriate multiple choice options for the prediction stage of their POE tasks. Student teachers used a web authoring package of their choice (eg. Dreamweaver or Frontpage) to build their tasks. They were required to write a rationale for their task designs and these were collected as data to probe how well student teachers had used existing literature to inform their designs. Semi-structured interviews took place with teachers after this construction phase and they also completed a questionnaire at this point. The actual multimedia tasks created by the student teachers were collected as data for the study.

The next phase of the study took place during the student teachers' practicum when they used their web based POE tasks with small groups of school students. Semi-structured interviews were again conducted with focus groups of student teachers after this implementation phase and they completed a final questionnaire containing free response questions and 5 
Likert type items. The children's task responses were collected as artefacts for the project.

In summary, twenty-one student teachers were asked to develop a multimedia based POE task for their own (K-12) students, and their work was analysed in terms of what types of understandings and reflections about science content and pedagogy were developed through this process. Data were collected using questionnaires, focus group interviews, observation and collected documents and artefacts.

\section{Overview of teachers' final tasks}

The prospective teachers created their multimedia based POE tasks using we based templates (or 'eShells') designed by Kearney and Wright (2002) to support teachers' construction of their own photographic, sound or video based POE tasks. These POE eShells provided two possible formats: a drawing format for tasks requiring more open ended responses and a multiple choice format for tasks with demonstrations where possible outcomes were limited. The templates also included a commitment section (see Figure 2) where learners working in small groups on their task could indicate their individual level of commitment to their initial predictions before advancing to the reasoning and observation stages. Figures 1 to 4 show screen shots of selected pages from a sample task designed for secondary physics students. In this task, the student teacher built a toy sailing boat and filmed the scenario of an electric fan blowing air on to the

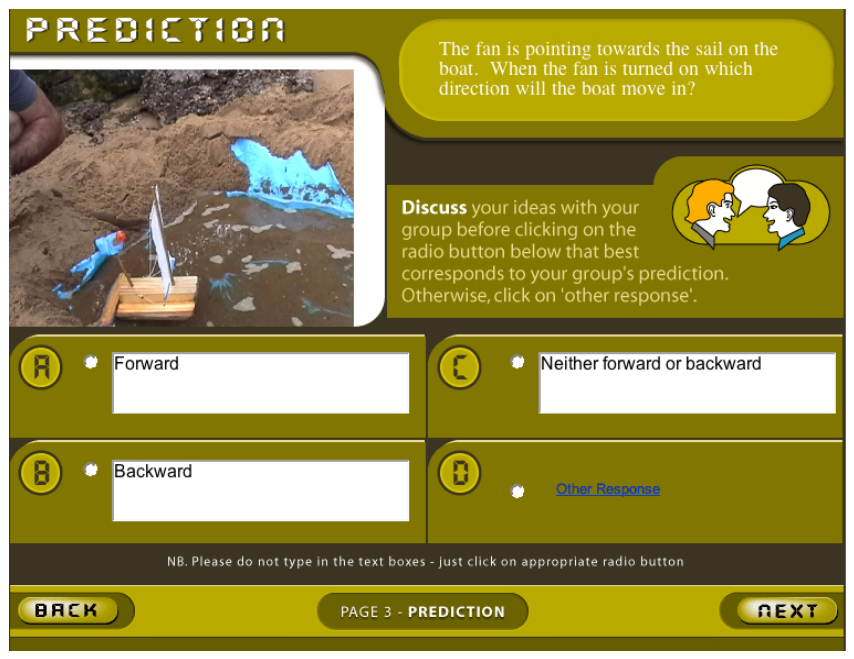

Figure 1: Prediction stage of sample task 


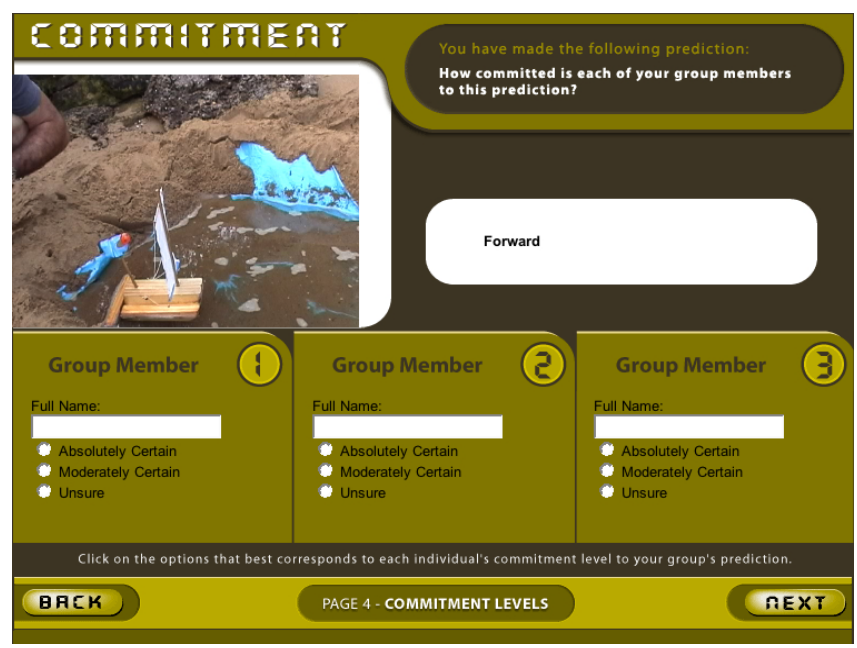

Figure 2: Commitment stage of sample task

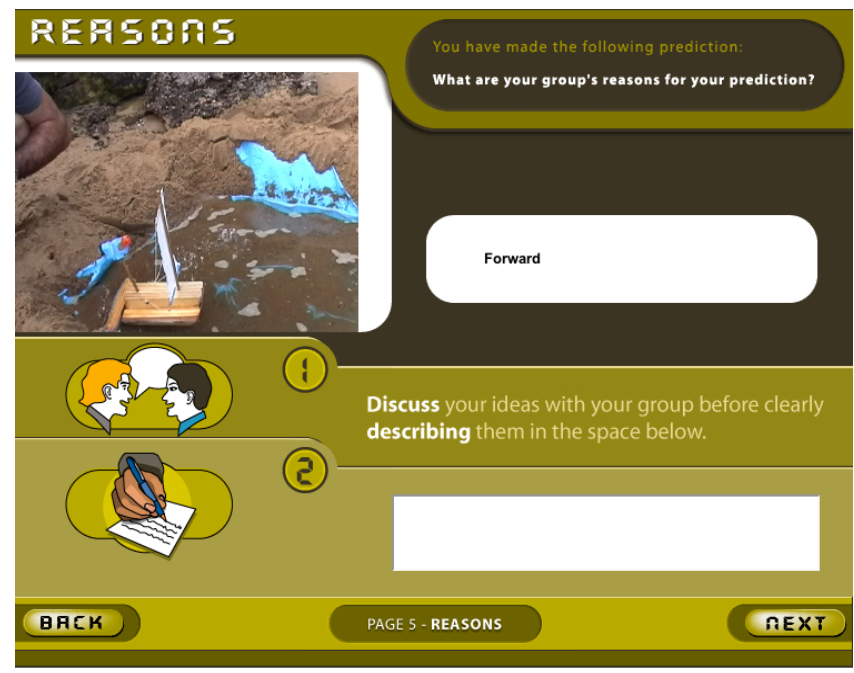

Figure 3: Reasoning stage of sample task

sail. She then created a second, related POE task with one crucial variable changed (the sail was taken away) - a technique encouraged by White and Gunstone (1992) (two other students created dual tasks in this way). An overview of other sample tasks created by the teachers is outlined in Table 1. The majority of teachers chose to create their own (mainly video based) demonstrations while the others chose to find a pre-existing demonstration 
from the Internet. For example, many student teachers who chose an astronomy theme found suitable photographic images from the web for inclusion in their task. Most teachers chose a context within the physical sciences. Only three teachers chose a life science theme. All task designs can be accessed from the online POE Task Library at http://www.eddev.uts.edu.au/teachered/poe/tasks/poehome.html

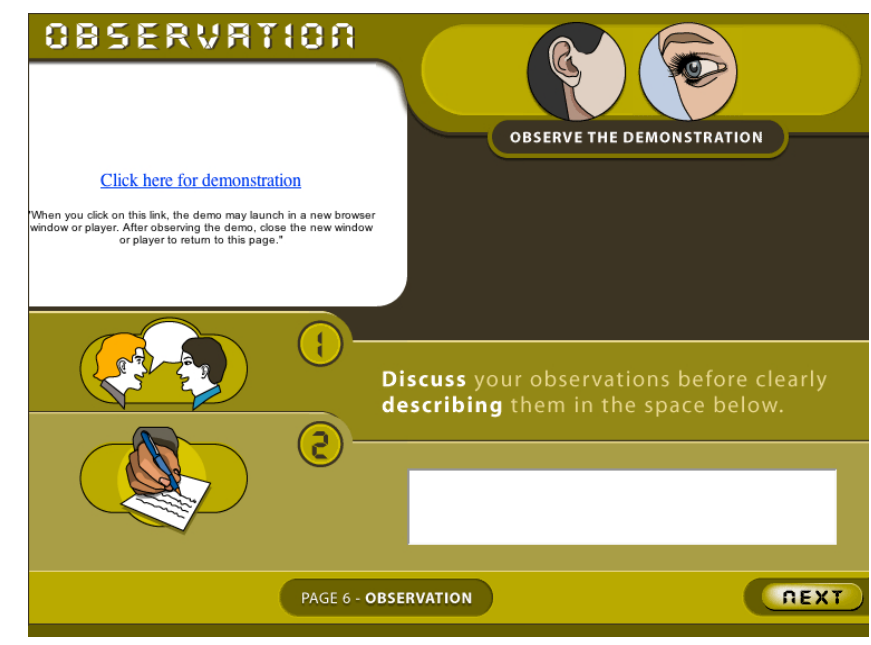

Figure 4: Observation stage of sample task

\section{Findings}

Findings are informed by mostly qualitative data from group interviews, individual questionnaires and student teacher artefacts (their final POE tasks and their rationales). Prospective teachers developed critical insights into the POE learning strategy and its underpinning learning principles, developed their own science content knowledge and ICT competencies. They developed an ability to critique the learning design and acknowledged that the POE procedure has its weaknesses and limits. They became more sensitive to children's world views and more developed astute insights into children's science learning processes. Quantitative data from 5 Likert-style items in the final questionnaire supported these claims (see Table 2).

This data particularly emphasised teachers' perceptions that the whole design and implementation process provided a positive model of effective use of ICT in teaching and learning (see item 4). 
Table 1: Description of sample online POE tasks from study

\begin{tabular}{|c|c|c|}
\hline $\begin{array}{c}\text { Title/Topic } \\
\text { (type of demo.) }\end{array}$ & $\begin{array}{c}\text { Description } \\
\text { (from Introduction Screen) }\end{array}$ & $\begin{array}{l}\text { Key Question } \\
\text { (Response type) }\end{array}$ \\
\hline $\begin{array}{l}\text { Sailing boat } \\
\text { Newton's Laws } \\
\text { (Video) }\end{array}$ & $\begin{array}{l}\text { It's a great day to go sailing, there is } \\
\text { no breeze and the sun is shining. The } \\
\text { use of a fan might help us or will it? }\end{array}$ & $\begin{array}{l}\text { The fan is pointing towards } \\
\text { the sail on the boat. When } \\
\text { the fan is turned on, which } \\
\text { direction will the boat move } \\
\text { in? }\end{array}$ \\
\hline $\begin{array}{l}\text { Bushfire } \\
\text { Regeneration. } \\
\text { (Photo) }\end{array}$ & $\begin{array}{l}\text { This is a photo of an area of National } \\
\text { Park near Sydney taken five days } \\
\text { after a bushfire swept through the } \\
\text { area. }\end{array}$ & $\begin{array}{l}\text { If you were to visit the same } \\
\text { area of National Park three } \\
\text { months after the fire, what } \\
\text { do you think is most likely } \\
\text { to have happened to the } \\
\text { trees in the picture? (M- } \\
\text { Choice format) }\end{array}$ \\
\hline $\begin{array}{l}\text { Liquids in } \\
\text { space } \\
\text { Astronomy } \\
\text { (Video) }\end{array}$ & $\begin{array}{l}\text { Here is some juice that was poured } \\
\text { into a glass }\end{array}$ & $\begin{array}{l}\text { You're now in a space } \\
\text { station, what would happen } \\
\text { to the juice if we spilt it? } \\
\text { (M-Choice) }\end{array}$ \\
\hline $\begin{array}{l}\text { Baked ice } \\
\text { cream } \\
\text { Heat / Insulation } \\
\text { (Video) }\end{array}$ & $\begin{array}{l}\text { We all like desserts. The ice cream is } \\
\text { placed on a pancake and then covered } \\
\text { in pink meringue (beaten egg whites) } \\
\text { before being placed in the oven. }\end{array}$ & $\begin{array}{l}\text { What will happen to the ice } \\
\text { cream when it is placed in a } \\
\text { hot oven for } 5 \text { minutes? (M- } \\
\text { Choice) }\end{array}$ \\
\hline $\begin{array}{l}\text { Ball in pool } \\
\text { Waves } \\
\text { (Video) }\end{array}$ & $\begin{array}{l}\text { Here is a tennis ball in a swimming } \\
\text { pool. At the left end of the pool a } \\
\text { person using a boogie board to create } \\
\text { waves. There is no wind present. You } \\
\text { will be focusing on what happens to } \\
\text { the ball once the waves reach it. }\end{array}$ & $\begin{array}{l}\text { In what direction will the } \\
\text { ball move when the waves } \\
\text { reach it? (Drawing) }\end{array}$ \\
\hline $\begin{array}{l}\text { Train } \\
\text { adventures } \\
\text { Motion } \\
\text { (Video) }\end{array}$ & $\begin{array}{l}\text { Joel is travelling home on a train } \\
\text { travelling forwards at approximately } \\
60 \mathrm{~km} / \mathrm{h} \text {. (It is not speeding up or } \\
\text { slowing down.) He will jump directly } \\
\text { up into the air while the train is still } \\
\text { moving (forward). }\end{array}$ & $\begin{array}{l}\text { Where will Joel land after } \\
\text { jumping directly up into the } \\
\text { air on the moving Train? } \\
\text { (He is currently at Point B } \\
\text { marked in photo) (M- } \\
\text { Choice) }\end{array}$ \\
\hline $\begin{array}{l}\text { Thunder and } \\
\text { lightning } \\
\text { Waves } \\
\text { (Video) }\end{array}$ & $\begin{array}{l}\text { You are sitting in a car watching } \\
\text { storm clouds in the distance. The } \\
\text { storm clouds are approximately } 25 \\
\text { kilometres away from your } \\
\text { position...the storm will produce } \\
\text { thunder and lightning soon! }\end{array}$ & $\begin{array}{l}\text { How will you observe the } \\
\text { thunder and lightning? (M- } \\
\text { Choice) }\end{array}$ \\
\hline
\end{tabular}

\section{Developing teachers' understanding and value of the POE teaching strategy}

Although they had covered the POE strategy in formal lectures, many student teachers had not seriously considered using the strategy in their teaching. Their design and implementation of a multimedia based POE 
task increased their value of this teaching strategy and the constructivist philosophy in which it is grounded. At the end of the whole process, many student teachers had developed an impressive insight into the strategy and valued it as a potential tool for their future teaching.

Table 2: Participants' responses from final questionnaire about teacher learning during the process of building their POE Tasks $(n=21)$

\begin{tabular}{|l|c|c|c|c|c|}
\hline $\begin{array}{l}\text { Item } \\
\text { The whole process of building } \\
\text { and implementing my } \\
\text { multimedia based POE task has } \\
\text { helped me .. }\end{array}$ & $\begin{array}{c}\text { Strongly } \\
\text { agree }\end{array}$ & Agree & Neutral & $\begin{array}{c}\text { Dis- } \\
\text { agree }\end{array}$ & $\begin{array}{c}\text { Strongly } \\
\text { disagree }\end{array}$ \\
\hline $\begin{array}{l}\text { 1. to build my knowledge of } \\
\text { teaching science. }\end{array}$ & 8 & 9 & 4 & 0 & 0 \\
\hline $\begin{array}{l}\text { 2. to build my understanding of } \\
\text { kids as science learners }\end{array}$ & 6 & 12 & 3 & 0 & 0 \\
\hline $\begin{array}{l}\text { 3. to revise and build on my own } \\
\text { science content knowledge }\end{array}$ & 4 & 12 & 4 & 1 & 0 \\
\hline $\begin{array}{l}\text { 4. to build my knowledge of or } \\
\text { attitude to using technology to } \\
\text { enhance kids' learning }\end{array}$ & 13 & 6 & 2 & 0 & 0 \\
\hline $\begin{array}{l}\text { 5. to build my own technical } \\
\text { competencies }\end{array}$ & 6 & 10 & 4 & 1 & 0 \\
\hline
\end{tabular}

Analysing the nature of the learning design

Teachers revealed impressive insights into the underpinning constructivist nature of the procedure. Bridie believed the real power was how the POE tasks either challenged or re-affirmed children's science views: "I became aware that you can use tools and strategies to deal with kids' misconceptions...you're challenging their concepts they have in their head - if they're wrong. If they're right, then you're re-affirming them." Isanne also appreciated the engaging nature of the procedure and the opportunity to help kids apply their knowledge to different contexts: "I think it's better than just showing them a demonstration. They have a chance to apply their previous knowledge and use what they know already to try and work out a new phenomenon they're discovering."

Like many students, Nasir appreciated the learner centred nature of the procedure, in contrast to more traditional didactic teaching methods. He also valued its effectiveness as a diagnostic tool:

You can gauge where they're at, what ideas they have about science - by getting them to predict stuff. They think about it a little bit more rather than the teacher going 'this is how it is, write it down!' ... I noticed a lot of discussion between my kids: 'What about this? What about that?' They were really focussed. 
Teachers also critically analysed each stage of the strategy. A number of student teachers thought the crucial part of the strategy was its requirement to commit to an outcome before viewing a demonstration. Ruby mentioned: "They have to think about what they already know and be prepared to put their money where their mouth is...their committing themselves to something - it makes them think more - 'well, what do I really think about that'?" Lynne believed the real power was the reasoning stage: "It's the reasoning behind them [the students' predictions] - that's where you really find out what they're thinking." Steve gave a detailed appraisal of the strategy in his interview, and also emphasised the reasoning stage:

The process draws out what they're understanding ... The reasoning part is probably the strongest-it's an endpoint for their ideas-belief in their ideas and then they use it to commit-to 'tell me why your beliefs are so weak or strong'.

However, Gordon believed the observation and explanation stages were the key to the strategy: "The strength is the observe and explain pages. The explain page helps develop metacognitive thinking - it helps people think about how their thinking. They know they are going to get to the explain page." However, some teachers acknowledged the challenging nature of the final 'explain' stage for students (especially younger children), and suggested a substitute 'development' stage, where learners could simply record any questions that arose from the task, using a variant predictobserve-develop strategy.

Insights into pedagogical issues

Student teachers were thoughtful about how they would fit their POE task into a unit of work and most agreed that how they used their POE tasks would depend on the level of complexity of the background concepts. To enhance peer learning opportunities, most teachers asked their students to work in pairs.

Many student teachers used their POE task as a diagnostic tool to probe children's pre-instructional science views and as introductory stimulus material for discussion. Beth said she'd use her task again in this way at the start of an astronomy unit: "The task was very effective in eliciting students' talk from which I was able to ascertain the level of the students' understanding about the earth's rotation as well as their misconceptions." Jane discovered that many of her kids did not recognise that the Earth spun on an axis and used her task as a springboard for discussion and other activities relating to seasons. Raja agreed that her tasks acted as stimulating preliminary material: "This is just an introductory task. I think it is good to introduce the concept and then you elaborate it more - another POE task or something else in class - it stimulates them and gets them interested and 
you can therefore plan other lessons." She found her students' responses were useful to her as a teacher: "We can see where they're at, how they think, what they know and don't know." Similarly, Steve observed motivational benefits using his POE in this way. He thought the real value of using his POE tasks at the start of the topic was that his students were motivated to further explore the topic:

What they thought would happen was the opposite of what actually did happen. So they actually said : 'when are we going to do this?' They actually were going to go there [the next lesson] with a different frame of mind about this topic.

Other student teachers decided to use their task as a revision exercise or as a summative assessment tool. Alarna decided to use her task as a revision tool, "after they've done their formal learning - to revise and 'put into practice'". Mary commented on using her 'butterfly life cycle' task as an assessment tool at then end of her unit of work: "I used it [my POE task] as an 'understanding task', particularly seeing how clearly the students can articulate the metamorphosis stage."

There was some concern about when and how to present the 'correct science views' relevant to each POE task. Some teachers wanted to add a hyperlink to the 'correct answer' at the end of their web based task to add closure. Others were happy to follow up their tasks with separate investigations and teacher presentations that dealt with relevant science concepts. For example, Jane's kids wanted to know the 'correct answers' after they completed their task: "They didn't want the task to be left open they wanted it "closed'!" Geoff strongly agreed:

It definitely needs a 'follow up'. I was quite concerned about students not able to confirm or deny their beliefs. Maybe they think they know it [the correct science view] but even if they get it right, they may have misbeliefs especially if they just stay in their peer group, propagating their misbeliefs in their peer group. The teacher needs an opportunity to 'correct misbeliefs' straight after task.

Student teachers such as Beth thought it was imperative to have a follow up lesson to address this issue: "The POE strategy is an excellent tool for establishing prior knowledge and for challenging children's science misconceptions. However, it does not stand alone. An explanation of the demonstration should be provided." Many student teachers placed a similar emphasis on following up their POE task with a class discussion of their responses and the correct science view. In this sense, they were thinking beyond the specific learning strategy to develop an understanding of how their task would fit into a broader (usually inquiry based) teaching model. 


\section{Developing teachers' insights into e-learning design}

Student teachers learned to distinguish the affordances and constraints of both e-learning and face to face environments. They recognised the benefits of using multimedia based demonstrations and the potential for supporting self paced learning and peer learning conversations. Their evaluations of the templates showed impressive insights into the multimedia based POE strategy.

\section{Justifying a computer mediated environment}

Data from student rationales indicated that most teachers developed a sound justification for using multimedia based science demonstrations (as opposed to doing a 'live' class demonstration). Most teachers chose demonstrations that were too time consuming, dangerous or simply impossible to do in a 'live', class based POE. Many chose astronomy as their topic for this reason: "Space is more inaccessible to students and therefore seemed a better task for an electronic POE" [from Raja's rationale]. Mikal was the only student teacher to choose a sound based demonstration and his rationale involved making a demonstration that was indeed too dangerous for kids to do:

I chose my topic because it is one that cannot be experienced in the classroom, nor could be investigated easily outside of the classroom. It involves the use of a motor vehicle and section of the road that the vehicle can travel at high speeds....

Many student teachers mentioned the out of class, realistic contexts made possible via multimedia. They thought these rich contexts were an important way for kids to link school science to their everyday lives. Lynne mentioned in her questionnaire: "I feel the [multimedia based] POE strategy brings science outside of the classroom and into the everyday events of life." Jack made similar comments: "One of the strengths of the POE strategy is the way it presents exciting ideas from science 'in your face'. Students are directly confronted with actual science and it forces them to immediately evaluate and explain."

Students also appreciated the opportunities afforded by the computer environment for learners to work independently and collaboratively. Mikal emphasised the autonomous nature of the computer supported procedure in his interview: "It allows for students to work independently and in small groups.... My POE task allowed students to look at their science misconceptions at their own pace." Furthermore, one of Janet's questionnaire responses showed her appreciation of the peer collaboration initiated by the tasks and also showed her value of the strategy: 
The tasks stress and promote the use of cooperative learning in that students have to collate information, engage in conversation and draw scientific conclusions when recording their results. Hence, students also learn from each other and develop social skills and teamwork skills.

Other lecturers in the course noted student teachers from the project referring to the POE strategy in their class discussions. For example, Jemma initiated an online discussion thread devoted to the POE strategy. A number of student teachers made postings to this forum indicating that they intend to use the multimedia based POE strategy in their future lessons. Indeed, Ruby believed that reflecting on the affordances of an online environment indirectly helped her develop simple ideas for more traditional, teacher led POE tasks in face to face, whole class situations.

Design issues with templates

Student teachers found the process of finding a suitable demonstration for their POE task time consuming but eventually developed insights into the type of phenomena appropriate for these tasks. They also found the writing process challenging, particularly on the opening pages. Suggested improvements to the templates pointed towards the need for a more child friendly version for use in primary schools.

Many students found the writing process demanding, especially the level of detail and choice of language on the crucial introductory and question pages. For example, Stuart said the most challenging part of the design process was "using kids friendly, appropriate language that is challenging without going over the top - pitching at the right level. You had to be clear and concise to help kids focus on the [subsequent] demonstration." Similarly, Jessica mentioned in her survey: "Choosing language on the first page [was challenging], and making sure you found the medium between enough detail to understand and too much detail to confuse."

Most student teachers, including less experienced computer users, were very positive about the templates and found them user friendly. However, many of the K-6 teachers thought the (designers') language used on the templates could be more child friendly and the graphic design needed revision for younger learners. For example, they suggested the commitment page could use a child friendly star or smiley face system instead of the words 'absolutely', 'moderately' etc. The opportunity to provide pictorial multiple choice options also was a commonly suggested improvement to any future versions. Other suggestions included an open ended written response option to supplement drawing responses and an audio recording facility for young children who have trouble typing or precisely communicating their science views in writing. 


\section{Developing teachers' understanding of children as science learners}

The prospective teachers talked passionately about their new perceptions of children's learning processes. They developed insights into collaborative learning and started to value the process of listening to children's personal science views via their conversations. They also expressed an increased awareness of children's alternative conceptions. Final questionnaire data indicated that $86 \%$ of students either agreed or strongly agreed with these claims - see item 2 from Table 2.

\section{Learning to listen to children and appreciating the benefits of children's learning conversations}

Teachers seemed to place great value on using their tasks as a vehicle to listen to children's science views via their learning conversations. For example, in her interview, Janet indicated that she had listened carefully to her students: "From listening to the children's responses, I learned that children have many unpredictable pre-conceived ideas. Their views are extraordinary and very imaginative." The whole process also helped Mary gain an insight into the children's world views: "The process helped me to view scientific ideas from a child's point of view." Furthermore, Lynne suggested listening to kids to initiate further ideas for creating more POE tasks. "The best ideas would come from listening to the students and their misconceptions." Indeed, Mary's final choice of demonstration (a time lapse video clip of a caterpillar's metamorphosis) was made after discussing ideas with a stage 3 child.

There was insightful analysis and speculation about which part of the POE process most strongly supports these peer learning interactions. Beth believed that the prediction phase was a key to eliciting these learning conversations: "The prediction is where I got to hear their thinking... that was good for insight [into their science views]. It also illustrated the power of prediction making in eliciting student talk." Although, Archie found the reason and commitment pages elicited more student talk: "There wasn't much discussion for their predictions but the 'reason and commitment' sections encouraged an increase in talk about why they were committed or not."

Student teachers thought critically about collaborative learning processes and developed insights into peer learning. Most encouraged their students to work on their tasks in pairs. For example, Isanne noticed her students' reviewing their ideas and talking to each other during the learning process: "They kept going 'no, it has to be this way! But it can't be because if this...' until they came to their idea ... they were bouncing off ideas...the talking helped them a lot." Mary agreed: "I also learned that kids working collaboratively greatly helps their science learning because it requires them 
to articulate and refine their ideas through their science conversation." However, Ruby touched on a potential weakness for group based POE tasks. She appreciated the diversity of student views in her class but was equally concerned about some students' lack of science discourse skills and their ability to reason and explain and defend their views:

I learned that the kids have very different ideas ... often, the child who selected the 'right answer' wasn't able to explain why he thought his answer was right and therefore he was over-ruled. Therefore, I think that often children do know the right answer but lack the understanding to explain 'why' in a scientifically acceptable way.

Students do need a certain level of language skills to effectively debate, clarify and defend their point of view in group situations and indeed, this issue was seen as important to address before attempting these types of tasks.

Learning about alternative conceptions in science education

Student teachers started to think carefully about children's alternative science views both during the design phase (eg. choosing a topic and multiple choice options that target common misconceptions) and also in the implementation phase when they elicited the children's personal science views.

In her interview, Lynne mentioned: "I just realised, when reading that book on misconceptions [to design her task]...just how many misconceptions children have in different areas-it's just unbelievable!" Most teachers expressed surprise at the exisiting alternative conceptions held by their children. Jennifer discovered a whole range of kids' misconceptions about heat from a misconceptions web page that helped inform her task design. Beth was surprised at the children's geocentric views elicited from their use of her task: "The children's perception [of the solar system] was dominated by the earth - they saw everything [in the solar system] as revolving around the earth." She later added: "This exhibition of misconceptions gave me some insight into children as science learners... I think the whole misconception thing was really made clear by doing this task-I didn't even know about misconceptions before!" Steve summarised:

I think that the strategy works down at a much deeper level for the student and the teacher looking at any misconceptions-especially at a conceptual level-that's where you have to 'dig'! You can't be looking at any misconceptions on the surface because they're actually well hidden.

Mikal also learned to appreciate the range of students' past experiences and the influence of these experiences on their science views: "I learned that all children come from different walks of life and have had different 
past experiences, which can reflect in their views of things." In this sense, student teachers enhanced their awareness of children's world views.

\section{Developing teachers' science content knowledge}

It was widely acknowledged by the student teachers that the process of designing a POE task encouraged them to review their own understanding of relevant science phenomena. Final questionnaire data indicated that $76 \%$ of students either agreed or strongly agreed with this claim (see item 3 from Table 2). Teachers engaged in debates and discussions with other adult peers about relevant concepts during the design phase and many discovered they had their own science alternative conceptions. The design process also seemed to sharpen their observation of everyday science phenomena.

\section{Reviewing their personal science views}

Teachers became aware of their own personal science views and recognised the need for an expert knowledge base before attempting to construct their POE tasks. For example, Alarna discovered she had misconceptions regarding moon phases, while Beth also discovered her own alternative conceptions in the area of local astronomy:

I had my own misconceptions and quite a few of them ... I found a good article on children's stages of local astronomy misconceptions and I realised that I was still in one of those stages ... I've noticed that when my own kids ask me something, I'm really going on my own prior knowledge, which could be wrong... the process [of making the POE task] enhanced my awareness of children's science misconceptions and my own!

Ruby became more aware of the fallibility of her own science knowledge base as she built her task: "I've got so many misconceptions-I don't know the scientific reason about many, many things." She too became aware that researching the accepted, correct science view was an essential part of making these POE tasks: "You do have to research, you have to know your topic; you can't just put something down [from your own belief system] because you might be wrong." Many student teachers found themselves consulting science books to clarify or revise their science content knowledge. For example, Isanne said she had reviewed and clarified her knowledge of butterflies whilst preparing her task:

I learned and re-capped! I had learned it before but didn't remember it before but now I understand properly about the processes...I researched it—so I could make sure the [prediction] question was appropriate [in her task].

Initiation of science learning conversations with adults

An interesting feature of the task design process was student teachers' frequent reports of in depth, engaging, science learning conversations with 
other adults, ranging from their own peers to expert scientists. Bridie and Lynne said they both spent quality time reviewing Newton's Laws and discussed various scenarios with their adult flatmates. Lynne acknowledged that her physics knowledge had benefited: "To be honest, Newton's Laws and in fact most of physics were not my strongest areas so by doing this POE task, it has helped me to understand Newton's 3rd Law better." Nasir also conducted in depth debates with his peers regarding the background science to his task (relative motion): "I've argued with people about mine so many times since I started making it. I've had in depth arguments with people - even adults disagreed with me!"

Similarly, Damien learned something new about corrosion through his discussions with outside professionals (he was not sure about the copper compound causing the green stain in his photos). He discussed this issue with three chemists and they all had different opinions! Indeed, Mikal consulted a secondary science teacher, two scientists and a road expert during his design process.

\section{Development of observation skills}

A number of student teachers said they started to observe natural phenomena more closely as they searched for suitable topics for their POE tasks. This was particularly the case for student teachers aiming to record and make their own demonstration. For example, Gabrielle found it difficult to think of a biology demonstration and finally came cross a heat demonstration 'as she was using the stove one day!':

\footnotetext{
It took me three weeks to think of a task! I was constantly looking around me saying: 'Right! What science is there around me right now? How could I make this significant?' However, one day as I was lighting my stove, the idea literally popped into my head!
}

Similarly, Nasir was on a train when his idea emerged: "I think you just need to keep your ears and eyes open... I was riding on the train and it dawned on me!" These comments were typical of teachers who chose to design and create their own photo, sound or video based demonstrations.

\section{Developing teachers' comprehensive ICT competencies}

A comprehensive view of teachers' ICT competence was advocated by DEST (2002), comprising the "collection of knowledge, skills, understandings and attitudes that are inextricably bound up with context and pedagogy" (p. 13). As well as improving their technical skills, student teachers in this study improved their attitudes towards and understanding of appropriate use of ICT to enhance science learning. Final questionnaire data indicated that a large majority of students either agreed or strongly agreed with this claim - see items 4 and 5 from Table 2. 
Developing teachers' confidence and technical competence levels

The prospect of developing technical skills was a major factor for many student teachers when volunteering for this project, especially the students with limited computer experience. Hence, it came as no surprise that many student teachers felt they had learned new skills ranging from filming and editing video and photos, to using web authoring software when manipulating the POE templates. Student teachers who filmed their own demonstrations recorded higher satisfaction levels and a sense of ownership and enhanced confidence. For example, Raja said: "I feel a lot more confident in my technical ability and was very proud of my finished product - I never thought I'd be able to make a software program." Alarna concurred: "I thought the task would be challenging in the technology aspects, however, it has actually made me more confident in using technology and computers." Interestingly, these same student teachers reported that their children also noticed and appreciated their own involvement in recording the demonstrations. For example, Janet mentioned in her interview that her kids were excited because they knew that she had filmed it: "The children conveyed how they enjoyed watching a real video filmed at my own house and outside the classroom."

Developing teachers' knowledge of the role of ICT in supporting learning

Student teachers thought that making the multimedia based POE tasks helped them to develop their attitudes toward and understanding of innovative uses of technology to support learning. Alarna liked how the technology supported active learning for kids: "It also showed me how technology can be used to make learning a lot more relevant, interesting and 'hands on' for children." Also, Bridie realised the potential of creatively using ICT in the classroom: "I feel like I can successfully attempt to use technology in different ways now, creating tasks to enhance kids' learning. I have a more positive attitude towards computers ... it's nice to see a creative way of using them in teaching." Ruby agreed: "I've realised that there is a lot of potential for the use of technology in the in the classroom that I am probably still not aware of." The development of student teachers' insights into the nature and pedagogy of multimedia supported POE tasks has also been discussed in previous sections.

\section{Summary and discussion}

A range of data sources were used to gain insights into the student teachers' learning experiences as they created their own online designs and used them in their own practicum classes. They insightfully critiqued and analysed the POE strategy and indeed, showed enhanced understanding of constructivist learning principles underpinning this strategy. They developed their knowledge of relevant pedagogy and reviewed and clarified their personal science views. They valued their own technical 
skills development, and built positive attitudes towards the use of ICT in their teaching. Furthermore, the application of their tasks in the school setting helped fine tune their thinking, and provided further insights into children's learning processes.

The trainee teachers also reported broader outcomes in terms of their teaching development. For example, Mary wanted to take the rich, interesting contexts inherent in her online POE tasks into other teaching strategies: "... by doing this [task], I believe I can create science lessons which are more relevant to students. It also showed me how important it is to gain students' initial interest in science lessons." Others were impressed by the active learning evident amongst kids engaging with their tasks and became motivated to emulate these conditions elsewhere in their face to face teaching settings. For example, Nasir mentioned: "I learned that children need to interact with science phenomena rather than just being taught about it." Ruby agreed: "I've learned that children really like to 'do' things and not only enjoy this more but learn more. So, providing children with many opportunities to interact with objects and each other is a positive teaching approach." Finally, the project helped Bridie realise that teaching is a complex business:

\footnotetext{
There are so many things to think about when planning a lesson - previous knowledge, level of language, interests, misconceptions, learning strategies, questioning etc. It has made me realise teaching science requires a lot of time and patience, as creating this task did.
}

Another interesting outcome was student teachers' exploration of potential variations of the POE strategy. For example, some students proposed a predict-observe-develop strategy to elicit learners' questions (in the develop stage), avoiding the difficult explain stage (especially for younger children). Also, some teachers found stimulating, interesting multimedia based demonstrations (particularly from the Internet) that were not suitable for a POE task as they were either too challenging, or required too much background information. For example, Bridie found a video clip of a plane breaking the speed of sound and forming a small 'cloud' wrapped around itself. Such 'digital scenarios' were interesting and thought provoking, and student teachers speculated about how they might use them in the classroom to promote discussion and questions; still fitting into an inquirybased teaching approach. Some teachers did experiment with these types of demonstrations as stimulus material in the classroom, using a variant observe-explain-develop strategy (again, eliciting learners' questions in the final develop stage). Hence, in these cases, the project encouraged teachers to investigate valid variations of an existing exemplary learning design.

The positive results of this study warrant further research in teacher education that focuses on both pre-service and practising teacher learning. 
Similar studies are needed to explore teacher development through their adoption and investigation of other exemplary learning designs in a range of discipline areas. Further research is also needed into the use of authoring tools such as the Learning Activity Management System (Dalziel, 2003), CopperCore (http://www.coppercore.org/), the RELOAD system (http://www.reload.ac.uk/) and the Instructional Architect system (http://ia.usu.edu/) as flexible test beds for teachers' designs. Also, the Smart Learning Design Framework (Lukasiak et al., 2005) promises unique opportunities for teacher education. These systems potentially provide teachers and researchers with greater flexibility for their adaptation and use of exemplary learning designs and also promote opportunities to explore and spawn new variations of existing designs.

\section{Conclusion}

Findings from this study indicate that student teachers' immersion in well researched, exemplary online learning designs may indeed help them bridge the gap between their university theory classes and practicum experiences. Trainee teachers in this study successfully designed their own online tasks using a sample, quality learning design (POE strategy supported by multimedia) and in the process, developed astute insights into the affordances and constraints of this design and also its underpinning constructivist learning principles. They extended their knowledge and sensitivity to the subtleties of children's learning processes, including their value of listening to children's personal views and the benefits of children's peer conversations. The whole design and implementation process helped the prospective teachers to review and clarify their own content knowledge and also develop better attitudes to and understandings of the role of technology in supporting learning.

\section{References}

Agostinho, S., Oliver, R., Harper, B., Hedberg, J. \& Wills, S. (2002). A tool to evaluate the potential for an ICT-based learning design to foster high-quality learning. In A. Williamson, C. Gunn, A. Young \& T. Clear (Eds), Winds of change in the sea of learning. Proceedings 19th ASCILITE Conference. (pp. 29-38). Auckland, New Zealand: UNITEC Institute of Technology.

http://www.ascilite.org.au/conferences/auckland02/proceedings/papers/164.pdf

Bennett, S., Lockyer, L. \& Agostinho, S. (2004). Investigating how learning designs can be used as a framework to incorporate learning objects. In R. Atkinson, C. McBeath, D. Jonas-Dwyer \& R. Phillips (Eds), Beyond the comfort zone: Proceedings 21st ASCILITE Conference (pp.116-122). Perth, 5-8 December. http://www.ascilite.org.au/conferences/perth04/procs/bennett.html 
Champagne, A., Klopfer, L. \& Anderson, J. (1980). Factors influencing the learning of classical mechanics. American Journal of Physics, 48(12), 1074-1079.

Dalziel, J. R. (2003). Implementing learning design: The Learning Activity Management System (LAMS). In G. Crisp, D. Thiele, I. Scholten, S. Barker and J. Baron (Eds.), Interact, Integrate, Impact: Proceedings 20th ASCILITE Conference (pp. 593-596). Adelaide, 7-10 December 2003.

http://www.ascilite.org.au/conferences/adelaide03/docs/pdf/593.pdf

Department of Education, Science and Training (DEST) (2002). Raising the Standards: A Proposal for the Development of an ICT Competency Framework for Teachers. [viewed 25 Oct 2005, verified 14 May 2006]

http://www.dest.gov.au/sectors/school_education/publications_resources/pr ofiles/raising_standards_ict_competency_framework.htm

Driver, R., Squires, A., Rushworth, P., \& Wood-Robinson, V. (1994). Making sense of secondary science: Research into children's ideas. New York: Routledge.

Duffy, T. \& Cunningham, D. (1996). Constructivism: Implications for the design and delivery of instruction. In D. H. Jonassen (Ed), Educational communications and technology (pp. 170-199). New York: Simon \& Schuster Macmillan.

Erickson, F. (1986). Qualitative methods in research on teaching. In M. Wittrock, (Ed), Handbook of research on teaching (pp. 119-161). New York: Macmillan.

Fang, Z. (1996). A review of research on teacher beliefs and practices. Educational Research, 38(1), 47-65.

Goodrum, D., Hackling, M. \& Rennie, L. (2001). The status and quality of teaching and learning of science in Australian schools: A research report. Canberra: DETYA. [verified 14 May 2006] http://www.dest.gov.au/sectors/school_education/ publications_resources/profiles/status_and_quality_of_science_schools.htm

Gunstone, R. (1995). Constructivism learning and the teaching of science. In B. Hand \& V. Prain (Eds), Teaching and learning in science. The constructivist classroom (pp. 3-20). Sydney: Harcourt Brace.

Kearney, M. (2002a). Description of Predict-observe-explain strategy supported by the use of multimedia. Learning Designs Website [viewed 25 Oct 2005, verified 14 May 2006] http://www.learningdesigns.uow.edu.au/exemplars/info/LD44/

Kearney, M. (2002b). Classroom use of multimedia-supported predict-observe-explain tasks to elicit and promote discussion about students' physics conceptions. Unpublished PhD dissertation, Perth: Curtin University of Technology.

Kearney, M. \& Wright, R. (2002). Predict-Observe-Explain eShell. Learning Designs Website. [viewed 25 Oct 2005, verified 14 May 2006] http://www.learningdesigns.uow.edu.au/tools/info/T3/

Laurillard, D. \& McAndrew, P. (2003). Reusable educational software: A basis for generic learning activities. In A. Littlejohn (Ed), Reusing online resources: A sustainable approach to e-learning (pp. 81-93). London: Kogan-Page. 
Lincoln, Y. \& Guba, E. (1985). Naturalistic inquiry. Newbury Park: Sage Publications.

Liew, C.W. \& Treagust, D.F. (1995). A POE teaching sequence for learning about understanding of heat and expansion of liquids. Australian Science Teachers Journal, 41(1), 68-71.

Lukasiak, J., Agostinho, S., Bennett, S., Harper, B., Lockyer, L. \& Powley, B. (2005). Learning objects and learning designs: An integrated system for reusable, adaptive and shareable learning content. ALT-J, Research in Learning Technology, 13(2), 151-169

Oliver, R. (2001). Learning objects: Supporting flexible delivery of online learning. In G. Kennedy, M. Keppell, C. McNaught \& T. Petrovic (Eds), Meeting at the crossroads: Proceedings of ASCILITE 2001, (pp 453-460). Melbourne: University of Melbourne.

http://www.ascilite.org.au/conferences/melbourne01/pdf/papers/oliverr.pdf

Oliver, R. \& Herrington, J. (2003). Exploring technology-mediated learning from a pedagogical perspective. Journal of Interactive Learning Environments, 11(2), 111126.

Palmer, D. (1995). The POE in the primary school: An evaluation. Research in Science Education, 25(3), 323-332.

Tobin, K. \& Tippins, D. (1993). Constructivism as a referent for teaching and earning. In K. Tobin (Ed), The practice of constructivism in science education (pp. 321). Hilldale, NJ: Lawrence Erlbaum.

Treagust, D., Duit, R. \& Fraser, B. (1996). Improving teaching and learning in science and mathematics. New York and London: Teachers College Press.

White, R. \& Gunstone, R. (1992). Probing understanding. London and New York: The Falmer Press.

Willis, J., Thompson, A. \& Sadera, W. (1999). Research on technology and teacher education: Current status and future directions. Educational Technology Research $\mathcal{E}$ Development, 47(4), 29-45.

Dr Matthew Kearney

Faculty of Education, Kuring-gai Campus

University of Technology, Sydney

PO Box 222 Lindfield NSW 2070, Australia

Email: matthew.kearney@uts.edu.au

Web: http://www.education.uts.edu.au/

http://www.ed-dev.uts.edu.au/personal/mkearney/homepage/ 